\title{
A PUBLICIDADE \\ DA JOHNNIE WALKER \\ E A CONSTRUÇÃO DE \\ IDENTIDADES MASCULINAS NA MODERNIDADE TARDIA
}

\section{LA PUBLICIDAD DE JOHNNIE WALKER Y LA CONSTRUCCIÓN DE IDENTIDADES MASCULINAS EN LA MODERNIDAD TARDÍA}

JOHNNIE WALKER'S ADVERTISING AND THE CONSTRUCTION OF MALE IDENTITIES IN LATE MODERNITY

Ana Paula Flores*

Universidade Federal de Santa Catarina

\begin{abstract}
RESUMO: Neste trabalho, são analisados seis publieditoriais de uma campanha da empresa de whisky Johnnie Walker, veiculados em revistas da Editora Abril, durante o ano de 2009. O objetivo principal é explicar a relação entre as práticas publicitárias e jornalísticas e a construção de identidades masculinas na modernidade tardia. Utiliza-se o escopo teórico da Análise Crítica de Gênero (ACG) aliado à perspectiva bakhtiniana. A campanha analisada selecionou homens, supostamente bem-sucedidos, para associarem uma imagem considerada positiva à marca, reforçando a representação do consumidor usual da bebida e da classe social a qual ele pertence. A narrativa característica desses textos põe em cena uma representação de sucesso masculino centrado no perfil de herói e em várias características provenientes do discurso neoliberal: o centro no indivíduo e em seu sucesso pessoal, o culto ao mercado empresarial e a valorização das ações empreendedoras.
\end{abstract}

PALAVRAS-CHAVE: Jornalismo. Publicidade. Masculinidade.

RESUMEN: En este trabajo se analizan seis anuncios de una campaña de la empresa de wiskhy Johnnie Walker, publicada en revistas de la Editorial Abril, durante el año de 2009. El objetivo principal es explicar la relación entre las prácticas publicitarias y periodísticas y la construcción de identidades masculinas en la modernidad tardía. Se utiliza el alcance teórico del Análisis Crítico de Género 
(ACG) combinado con la perspectiva de Bakhtin. La campaña seleccionó a hombres supuestamente exitosos, para asociar una imagen positiva a la marca, reforzando la representación del consumidor habitual de la bebida y la clase social a la que pertenece. La narrativa característica de estos textos retrata una representación del éxito masculino centrado en el perfil del héroe y en diversas características derivadas del discurso neoliberal: centrado/el centro en el individuo y en su éxito personal, el culto al mercado empresarial y la valorización de las acciones emprendedoras.

PALABRAS CLAVE: Periodismo. Publicidad. Masculinidad.

ABSTRACT: In this work, we analyzed six advertorials of Johnnie Walker's company, that were published in four Brazilian magazines during the year 2009. The main objective is to explain the relation between advertising and journalistic practices and the building of masculinity in late modernity. We use as reference the theoretical approaches of Critical Genre Analysis (CGA), associated with Bakhtin's theoretical framework. The Johnnie Walker selected individuals that are supposedly successful men, to associate an alleged positive image to the brand, reinforcing the usual representation of the beverage's consumer and the social class to which he belongs. The story characteristically shows a representation of male success linked to a heroic profile and to several characteristics coming from the neoliberal discourse: the individual and his success as the central aspect, reverence for businesses activities, and appreciation of entrepreneurship.

KEYWORDS: Journalism. Advertising. Masculinity.

\section{INTRODUÇÃO}

Textos que reúnem jornalismo e publicidade são cada vez mais comuns em diversas ordens de discursos institucionais da sociedade contemporânea (FAIRCLOUGH, 1992 [2001]). Para Fairclough (1992 [2001], p. 151), a profusão desses textos demonstra um movimento "[...] colonizador da publicidade do domínio do mercado de bens de consumo, num sentido estrito, para uma variedade de outros domínios”. Na avaliação de Gomes (2005; 2006; 2007) e Marshall (2003), esse fenômeno se deve a um movimento pósindustrial de inserção da publicidade em vários domínios, que acaba por produzir gêneros híbridos. O publieditorial ${ }^{1}$, como gênero jornalístico que é colonizado pela prática publicitária, pode ser considerado, no contexto da modernidade tardia, como resultante desse processo de hibridização e é o objeto de análise desta pesquisa.

Este trabalho procura enfocar as práticas sociais que estão na base do gênero jornalístico denominado "publieditorial", que pode aparecer de forma similar a uma reportagem, ou a outro gênero jornalístico, que seja colonizado pela prática publicitária. Neste trabalho, são analisados seis exemplares do gênero de uma campanha da empresa de whisky Johnnie Walker, coletados a partir das revistas Superinteressante, VocêS/A, VIP e Playboy. O objetivo principal é explicar o gênero publieditorial correlatamente às práticas sociais publicitárias e jornalísticas que ele constitui nessa campanha publicitária da Johnnie Walker. Para isso, busca-se responder à seguinte questão de pesquisa: Como o publieditorial da campanha "Aonde um passo pode te levar" da Johnnie Walker se constitui como gênero e prática social, e como constitui identidades (particularmente a masculinidade) no contexto da modernidade tardia?

\section{REFERENCIAL TEÓRICO}

A Análise Crítica de Gênero (ACG), abordagem teórica aqui adotada, tem sido discutida, principalmente, por Bhatia (2004), Bonini (2010, 2011) e Motta-Roth $(2004,2008$, 2011) e pode ser entendida, em sua fase inicial (MEURER, 2005; BHATIA, 2004), como uma aproximação de duas áreas de estudos, a Análise de Gênero de orientação sociorretórica, tendo como principal representante John Swales (1990), e a Análise Crítica do Discurso (ACD), conforme proposta por Fairclough (1992, 2001, 2003). Nesses termos, a ACG propunha a execução combinada da análise de elementos linguísticos e retóricos do texto (como na Análise de Gênero estrita) com a análise dos elementos ideológicos do contexto (como a Análise Crítica do Discurso) (MOTTA-ROTH, 2008). Conforme ainda pontua Motta-Roth (2008), a ACG promove uma análise que é, "[...] ao mesmo tempo, detalhada, porque explica e localiza os elementos linguísticos no tempo e no espaço, e problematizadora, porque desnaturaliza os valores que estão postos [...]” (2008, p. 370). Além disso, a teoria de gêneros combina, ao mesmo tempo, as vantagens de uma visão geral dos usos da língua com sua

${ }^{1}$ Contração usada para se referir a um “editorial publicitário”, em inglês advertorial. 
realização mais específica. Nesse sentido, Bhatia afirma que a análise de gêneros é "[...] estreita em seu foco e ampla em sua visão" (2009, p. 164).

Lima (2013) discute como ocorre essa aproximação entre a ACD e a ACG. Para ele, enquanto a Análise de Gênero vem se movendo em direção a questões discursivas mais amplas, a Análise Crítica do Discurso mostra cada vez mais interesse em tomar o gênero como uma ferramenta teórica fundamental para a compreensão das práticas sociodiscursivas.

Noutras palavras, se por um lado, os analistas de gênero se mostram cada vez mais preocupados em investigar os aspectos do contexto social que incidem nas práticas discursivas genéricas [...] por outro, os analistas do discurso se mostram cada vez mais interessados em desvendar o papel do gênero nas construções e ações do discurso. (LIMA, 2013, p. 32)

A ACD detém uma visão multidisciplinar dos estudos da linguagem e de práticas sociais, buscando estudar diferentes fenômenos discursivos que estão relacionados, sobretudo, a questões de poder, ideologia e discriminação.

Motta-Roth (2008) assevera que Fairclough $(1995,2003)$ contribui de forma especial para o pensamento crítico, porque ele revela um objetivo intervencionista e emancipador ao buscar "[...] desvelar os elementos do sistema de relações sociais presentes no discurso e tentar avaliar os efeitos desses elementos sobre as relações sociais [...]” (p. 362). Fairclough (2003) entende os discursos como formas de representar aspectos do mundo: os processos, relações e estruturas do mundo material, o mundo dos pensamentos, dos sentimentos, e das crenças e o mundo social. Além de representação, o discurso se materializa na sociedade na forma de relações sociais e identidades:

Diferentes discursos são diferentes perspectivas do mundo, e eles estão associados a diferentes relações que as pessoas têm no mundo, as quais dependem das suas posições no mundo, das suas identidades sociais e pessoais e das relações sociais nas quais elas interagem com outras pessoas. Discursos não apenas representam o mundo como ele é (ou melhor, como é visto), eles são também projetivos, imaginários, representam possíveis mundos que podem ser diferentes do mundo real, e articulados a projetos de mudança do mundo em direções particulares. As relações entre os diferentes discursos são um elemento das relações entre as diferentes pessoas elas podem se complementar, competir entre si, uma pode dominar as outras e assim por diante - manter-se separadas um das outras, cooperar, competir, dominar - e buscar mudar os meios através das quais se relacionam entre si. (FAIRCLOUGH, 2003, p. 124, tradução da autora)

Como esclarece Meurer (2005), com relação ao gênero, entretanto, Fairclough não desenvolve uma teoria consistente. Essa limitação, no entanto, salienta Meurer, não invalida as vantagens que o modelo oferece "[...] em termos do seu avanço em direção à integração de uma teoria linguística e de uma teoria social" (2005, p 103).

Por conta dessa lacuna, tanto Bonini (2012) quanto Motta-Roth e Marcuzzo (2010) acrescentam a perspectiva bakhtiniana ao quadro teórico da ACG, no que tange ao conceito de gênero. Utilizando-se, por exemplo, além de outros aportes teóricos, do conceito de polifonia de Bakhtin ${ }^{2}$, Motta-Roth e Marcuzzo (2010) fazem uma análise do modo como diferentes vozes se manifestam em 30 exemplares de notícias de popularização científica coletados em dois sites: BBC News e Scientific American. As autoras consideraram que, ao mobilizar diferentes posições enunciativas (pesquisador, colegas e entidades, governo, público, o próprio jornalista), a mídia desempenha três funções discursivas: informa sobre novas descobertas, explica conceitos científicos e esclarece a relevância da pesquisa para a sociedade. Os resultados demonstraram a hegemonia da voz da ciência e a presença tímida da perspectiva dos cidadãos na análise da relevância das pesquisas para a sociedade. Para Motta- Roth (2008), a referência aos escritos de Bakhtin nos estudos de gêneros discursivos favorece a contextualização do discurso e os aspectos externos da constituição do gênero:

\footnotetext{
${ }^{2}$ Compreende-se que existe uma polêmica que envolve a autoria dos trabalhos de outros autores que integravam o grupo de estudos de Bakhtin. No entanto, não é objetivo deste trabalho entrar no mérito dessa questão, por esse motivo, optou-se por adotar a menção à teoria de Bakhtin.
} 
[...] o conceito de gênero é cada vez mais expandido para além dos limites do léxico e da gramática, para abarcar o contexto social, o discurso e a ideologia... Tal expansão demanda que as análises considerem as condições de produção, distribuição e consumo do texto, e focalizem os textos que circulam na sociedade contra o pano de fundo do momento histórico. Olham-se as finalidades e a organização econômica dos grupos sociais, em termos de vida cotidiana, negócios, meios de produção, formações ideológicas, etc., que determinam o conteúdo, o estilo e a construção composicional dos gêneros. (MOTTA-ROTH, 2008, p. 351)

Na ACG, o gênero assume um papel de destaque, sob a perspectiva de que ele realiza um conjunto de práticas sociais (BONINI, 2010). Dessa forma, o gênero é analisado para atingir uma compreensão crítica da(s) prática(s) social(ais) de que ele se constitui. Para Motta-Roth (2008), a ACG considera as condições de produção, distribuição e consumo do gênero, o momento histórico e lança um olhar para o texto com o objetivo de interpretar a prática social da qual ele faz parte. Ao preocupar-se com as práticas sociais, afirma a autora, a ACG "[...] esclarece o significado dos textos para a vida individual e grupal e o papel estruturador dos gêneros para a cultura” (p. 370).

\subsection{JORNALISMO, PUBLICIDADE, MANIPULAÇÃO E MODERNIDADE TARDIA}

Para analisar os mecanismos de hibridização dos discursos jornalístico e publicitário, realizados pelo gênero publieditorial, faz-se necessário compreender a manipulação da mídia impressa no contexto da modernidade tardia. Esse conhecimento dos mecanismos de funcionamento da mídia é essencial para saber como ler e compreender o que vemos e ouvimos.

A modernidade tardia (inicialmente discutida em GIDDENS, 1991) é considerada uma nova fase da vida social que é resultado, segundo Chouliaraki e Faiclough (1999), de um período de profundas transformações econômicas, políticas e sociais, em escala global, que se iniciou na década de 80:

Economicamente, tem havido uma mudança do modelo 'Fordista' de produção e consumo de bens em massa para a "acumulação flexível". [...] Ao mesmo tempo, as unidades de produção são cada vez mais transnacionais. Politicamente, o 'neo-liberalismo se estabeleceu internacionalmente. Essas mudanças econômicas profundas têm sido descritas como a introdução de uma nova era "pós-industrial" na organização do capitalismo moderno. [...] Os avanços na tecnologia da informação, principalmente os meios de comunicação, estão subjacentes as duas transformações econômicas e culturais, abrindo-se novas formas de experiências e conhecimentos e novas possibilidades de relacionamento com os outros através da televisão ou da internet. (CHOULIARAKI; FAIRCLOUGH, 1999, p. 3, aspas conforme original, tradução da autora)

Nesse contexto social é que Abramo (2003) constata que os órgãos de comunicação, como parte integrante da indústria cultural, estão inegavelmente submetidos à lógica econômica do capitalismo: "Mas o capitalismo opera também com outra lógica - a lógica política, a lógica do poder - e é aí, provavelmente, que vamos encontrar a explicação da manipulação jornalística” (ABRAMO, 2003, p. 43). O poder oculto do discurso da mídia, segundo Fairclough (1989 [2001]), aliado à capacidade dos detentores de poder do capitalismo de exercer esse poder, depende das tendências sistemáticas das notícias e de outras atividades da mídia. Para o autor, um texto isolado é insignificante: "Os efeitos do poder da mídia são cumulativos, funcionando por meio da repetição de modos particulares de manipular causalidade e agência, modos particulares de posicionar o leitor e assim por diante" (FAIRCLOUGH, 1989 [2001], p. 45).

A manipulação é uma prática social discursiva de grupos dominantes que serve à reprodução do seu poder. Van Dijk (2010) considera que esses grupos dominantes podem fazer isso de várias formas: “[...], por exemplo, através da persuasão, fornecendo informações, educação, instrução e outras práticas sociais que objetivam influenciar o conhecimento, as crenças e (indiretamente) as ações dos receptores" (VAN DIJK, 2010, p. 237).

O gênero publieditorial, caracterizado pela hibridização entre as esferas do jornalismo e da publicidade, ou seja, entre informação e promoção, pode conter elementos de manipulação, já que influencia seus interlocutores a perceberem a empresa de uma determinada maneira. 
Além disso, percebe-se que a empresa veiculou uma campanha publicitária com aparência de perfil jornalístico para atingir maior aceitação do público leitor das revistas e criar identificação entre o consumo do produto e o sucesso profissional. Esse aspecto será analisado com mais detalhes nos itens 4.1 e 4.2 a seguir.

\section{METODOLOGIA}

O objetivo desse trabalho é explicar o gênero publieditorial correlatamente às práticas sociais publicitárias e jornalísticas que ele constitui no interior de uma campanha publicitária da Johnnie Walker, verificando como essas práticas constroem a identidade masculina. Para atingir esse objetivo, delineou-se uma análise que vai do gênero às práticas sociais que ele (re)produz (a campanha publicitária, a representação do produto, a representação do consumir, etc.). Em especial, foram propostos procedimento para focalizar dois aspectos:

1) para explorar o aspecto da hibridização do gênero, procedeu-se à descrição da organização do gênero e à análise da(s) prática(s) social(is) que lhe serve $(\mathrm{m})$ de base (notadamente, a campanha publicitária). Em um segundo momento, foram elencados e classificados os elementos que compõe essa campanha;

2) para lançar luz sobre os modos de constituição da masculinidade, passou-se na sequência a uma análise do discurso presente nesses textos.

Dos seis publieditoriais analisados, dois foram coletados da revista Você $S / A$, outros dois da VIP, um da Superinteressante e outro da Playboy ${ }^{3}$. O período de publicação desses textos vai de novembro a dezembro de 2009 (Quadro 1). A seleção foi feita por meio de pesquisa no acervo de periódicos da Biblioteca da Universidade Federal de Santa Catarina, da Biblioteca do Estado e em um sebo de Florianópolis. Após a busca no acervo foi feito o escaneamento em formato Portable Document Format (PDF) dos exemplares do gênero.

\begin{tabular}{c|c|c} 
Título & Revista & Edição \\
\hline A água nossa de cada dia & Superinteressante & Dezembro/2009 \\
\hline Céu de brigadeiro & Você S/A & Novembro/2009 \\
\hline No caminho dos astros & Você S/A & Dezembro/2009 \\
\hline Um expert das baladas & VIP & Novembro/2009 \\
\hline Game over? Sem chance! & VIP & Dezembro/2009 \\
\hline Uma conquista com sabor & Playboy & Novembro/2009
\end{tabular}

Quadro 1: Lista de exemplares coletados nas revistas Fonte: Criação da autora

\section{ANÁLISE}

A campanha intitulada "Aonde um passo pode te levar" é formada por diversos relatos, e nesta pesquisa, de forma não exaustiva, teve-se acesso a seis deles (conforme listados no Quadro 1). Antes da publicação da campanha, a empresa veiculou nas revistas um anúncio conclamando seus leitores a enviarem histórias sobre "trajetórias, coragem e inspiração" (Figura 1).

\footnotetext{
${ }^{3}$ A autora teve acesso a todas as revistas Superinteressante e Você S/A de 2009 e 2010, por meio do acervo da UFSC e da Biblioteca Pública do Estado. Em relação às revistas VIP e Playboy houve uma dificuldade maior em localizar os exemplares, já que se tratam de revistas com conteúdo erótico/pornográfico e não estão disponíveis para consulta em bibliotecas. A autora precisou comprar os exemplares em um sebo da capital, mas não teve acesso à revista Playboy de dezembro de 2009, o que poderia ampliar o corpus para a análise, pois não a encontrou em nenhum sebo para adquirir. Desse modo, salienta-se que a coleta do corpus para a análise não foi feita de forma exaustiva.
} 


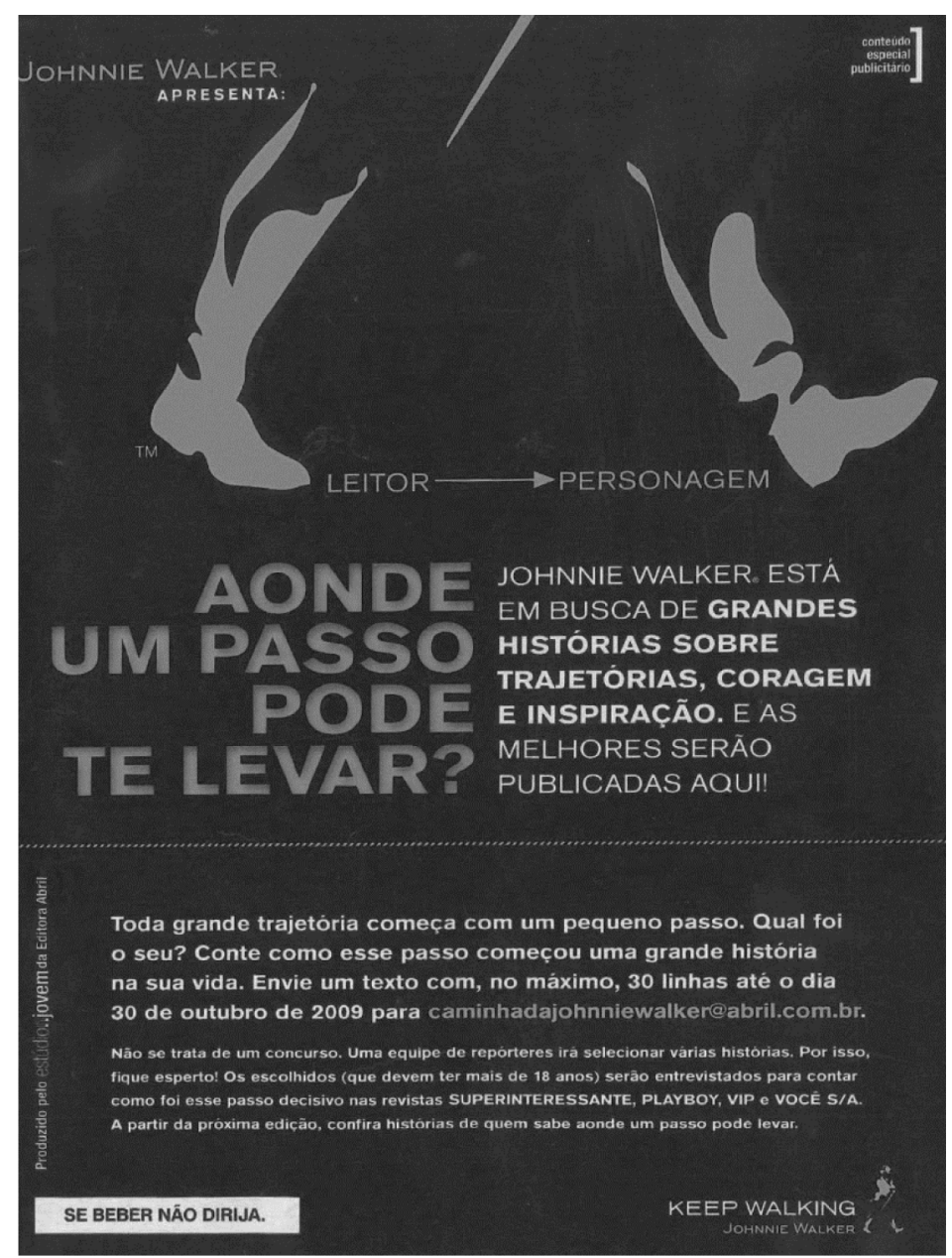

Figura 1: Apresentação da campanha

Fonte: Revista Superinteressante (Outubro/2009)

O texto inicial é estruturante da campanha, pois cumpre a função de, ao mesmo tempo, anunciar a campanha e criar meios para que os demais textos sejam produzidos. Os textos centrais são, portanto, os que se seguem a esse primeiro (eles foram reproduzidos nos anexos deste trabalho). Neles é que aparecem as histórias de vida (marcadamente de superação) conformadas como o gênero publieditorial. Trata-se de um tipo de configuração possível, pois o publieditorial pode fazer uso de diversos gêneros e mecanismos discursivos, tanto da publicidade quando do jornalismo.

Verificou-se que a campanha compõe-se basicamente de dois conjuntos de elementos verbais: os jornalísticos e os publicitários. Esses elementos estão destacados respectivamente em azul e vermelho (Figura 2). No conjunto jornalístico (que nos interessa nesta análise) encontram-se quatro elementos (LAGE, 2005): o título, que é padrão em todos os exemplares do gênero (Aonde um passo pode te levar?); o subtítulo, que abre o texto; o perfil, texto que ocupa de 20 a 26 linhas, escrito em um parágrafo único e o olho, elemento de edição que traz um depoimento de uma pessoa e é colocado em destaque no lado esquerdo da página. O agrupamento publicitário reúne outros quatro elementos. O primeiro é a marca da Johnnie Walker, que aparece em dois locais: no topo e no pé da página. No topo, ela serve como apresentação do conteúdo, demarcando claramente que a página é publicitária. No pé da página, a marca é usada com seu slogan (Keep walking), que está diretamente relacionado à imagem do sujeito retratado e perpassa todo o conjunto de textos do gênero. O segundo elemento é um rótulo que diz respeito à produção do material e aparece no canto direito da página (Produzido pelo estúdio NJovem da Editora Abril). No canto superior direito, há outro rótulo, que define o conteúdo como sendo de caráter publicitário. O terceiro item é um letreiro com a frase "Se beber não dirija”, que aparece no pé da página e é uma advertência de caráter obrigatório, determinada por uma resolução da Agência Nacional de Vigilância Sanitária (Anvisa) ${ }^{4}$.

\footnotetext{
${ }^{4}$ A resolução determina que nas propagandas em jornais e revistas a advertência deva ser inserida em retângulo de fundo branco, emoldurada por filete interno, em
} letra de cor preta, padrão Humanist 777 Bold ou Frutiger 55 Bold caixa alta. Fonte: http://www.anvisa.gov.br/propaganda/consulta_minuta.pdf. 
Finalmente, considera-se como um item intertextual e híbrido ${ }^{5}$ a imagem do sujeito caminhando, à semelhança da logomarca da empresa de bebidas. Dessa forma, essa imagem, no perfil, serve de elo entre a esfera publicitária e a jornalística (CARDOSO, 2008).

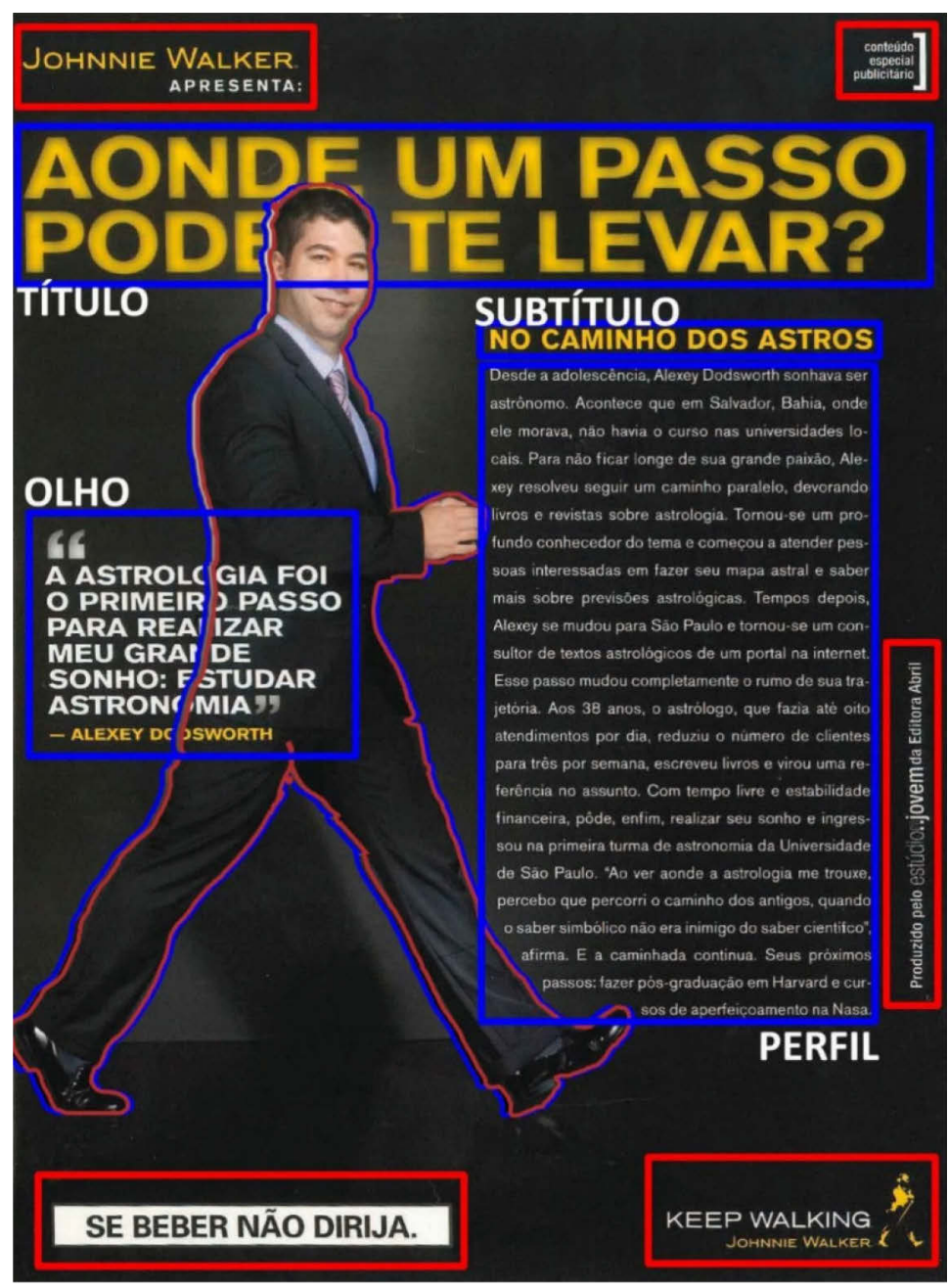

Figura 2: Conjunto de elementos da campanha

Fonte: Você S/A (Dezembro/2009)

A campanha demonstra ter como objetivo primordial a divulgação da marca de whisky Johnnie Walker. Para compreender o funcionamento dos anúncios publicitários selecionados, é fundamental recorrer à legislação que trata da publicidade de bebidas alcoólicas no Brasil. A propaganda desse tipo de produto é restringida pelo fato de se configurarem como itens de consumo restrito e impróprios para determinados públicos e situações. A lei nº 9.294/1996 (BRASIL, 1996) é a principal regulamentação brasileira que estabelece os princípios nos quais a propaganda comercial de bebidas alcoólicas deve se basear. Ao serem proibidas de utilizar na propaganda meios que induzam diretamente ao consumo, as empresas de bebidas alcoólicas podem optar por criar peças publicitárias que disfarcem a situação, apelando para um alto nível de tecnologização do discurso ${ }^{6}$. Dessa forma, a maioria delas investe na chamada propaganda de imagem, cujo foco é no estilo de vida do usuário do produto, em vez de abordar o valor do produto em si. Conforme Moreira Júnior (2005), a propaganda de imagem, “[...] com graus variados de sutileza, sugere que os estilos de vida mostrados podem ser alcançados por meio do uso da mercadoria anunciada. Nesse tipo de publicidade, raramente se faz alguma menção à qualidade do produto [...]" (2005, p. 17). Isso leva a publicidade do álcool a explorar temas relacionados à sexualidade, virilidade e ao sucesso pessoal. Os dois primeiros estão muito presentes nas propagandas de cerveja; já o terceiro tema pode ser claramente visualizado no conteúdo veiculado nas peças da Johnnie Walker, objeto de estudo deste trabalho.

\footnotetext{
${ }^{5}$ Por esse motivo, a imagem do perfilado aparece contornada com as cores azul e vermelha.

${ }^{6}$ Uma estratégia similar é descrita no estudo de Ramalho (2009), quando um mídia card é usado para anunciar indiretamente um remédio, para o qual a publicidade também é proibida no Brasil.
} 
Fairclough (1992 [2001], p. 143) identificou esse processo de tecnologização do discurso como uma importante dimensão do consumismo e como uma mudança no poder dos produtores sobre os consumidores: "[trata-se] de uma tendência mais ampla para os produtores comercializarem suas mercadorias em formas que maximizem sua adaptação aos estilos de vida e as aspirações de estilos de vida dos consumidores (embora eu acrescente que eles estão buscando construir as pessoas como consumidores e os estilos de vida a que elas aspiram)".

Concebido essencialmente como instrumento de autodisciplina da atividade publicitária, o Código Brasileiro de Autorregulamentação Publicitária foi instituído em 1980, por diversas entidades representativas do mercado brasileiro de publicidade. O documento apresenta, em um anexo que se ocupa das categorias especiais de anúncios, diversos tópicos relacionados ao que denomina "Princípio do consumo com responsabilidade social". Esse princípio postula que não sejam utilizadas "[...] imagens, linguagem ou argumentos que sugiram ser o consumo do produto sinal de maturidade, ou que ele contribua para maior coragem pessoal, êxito profissional ou social [...]" (FAIRCLOGH, 1980, p. 35). A campanha da Johnnie Walker parece ir de encontro a esse princípio, ao associar o passo que representa sua identidade corporativa à caminhada que levou os sujeitos das histórias descritas ao que consideram sucesso (Figuras 3 e 4). Vejamos os exemplos textuais abaixo:

(1) "Este ano, Mauro deu outro grande passo [...]"

(Céu de brigadeiro)

(2) "Esse passo mudou completamente o rumo de sua trajetória"

(No caminho dos astros)

(3) “[...] ele e os sócios deram outro passo importante em sua trajetória [...]"

(A água nossa de cada dia)

Além do elemento verbal, essa vinculação também está evidenciada na imagem do sujeito caminhando, que se constitui em uma metáfora visual, pois atrela o ato de superação do consumidor à marca, ou seja, indiretamente impelindo-o a beber para superar, ou a superar para beber.

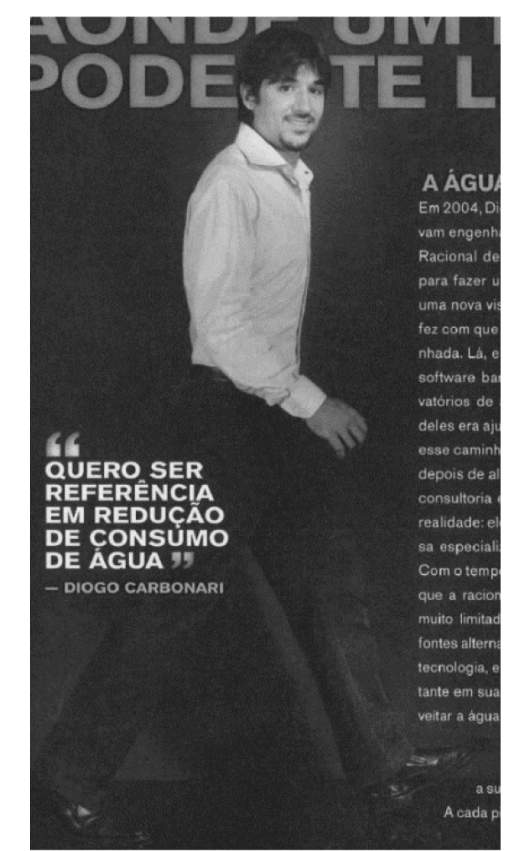

Figura 3: Recorte da foto do sujeito caminhando Fonte: Recorte do anúncio

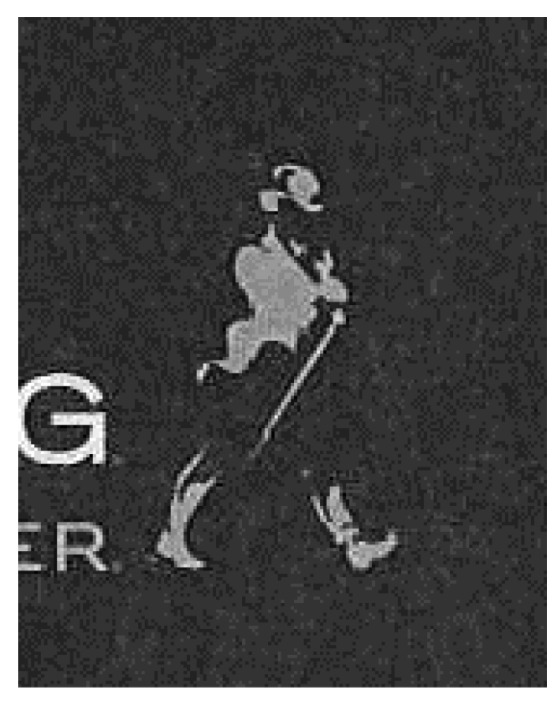

Figura 4: Marca da empresa situada no canto direito da página

Fonte: Recorte do anúncio 


\subsection{O GÊNERO PUBLIEDITORIAL E A HIBRIDIZAÇÃO JORNALÍSTICO-PUBLICITÁRIA}

Apesar de o gênero selecionado nas revistas ser visivelmente rotulado de "conteúdo especial publicitário"7, pode-se afirmar que os textos da campanha da Johnnie Walker constituem-se como um gênero híbrido, o publieditorial. Ao mesmo tempo em que esses textos pretendem divulgar e promover a marca, buscam construir uma abordagem mediadora de eventos por meio do discurso jornalístico e, no caso dessa campanha da Johnnie Walker, expõe-se a trajetória de um determinado sujeito, por meio de um texto jornalístico conhecido como perfil.

O perfil é geralmente um texto de extensão curta, publicado em jornais e revistas, que focaliza determinados momentos da vida de uma pessoa. Outra expressão que também se aplica ao perfil, proveniente das pesquisas em Ciências Sociais é "histórias de vida". Como esclarece Vilas Boas (2003), o perfil é uma narrativa sobre a vida de um indivíduo e, nesse sentido, busca "[...] humanizar um tema, um fato ou uma situação contemporânea. Na sua versão mais abreviada, a história de vida examina episódios específicos da trajetória do protagonista [...]" (2003, p. 16). Para o autor, o ponto central do perfil é a experiência humana do personagem real ${ }^{8}$. Dessa forma, o perfil expressa uma trajetória, por mais sintética que seja. Ainda de acordo com Vilas Boas (2003), foi a partir da década de 1930 que jornais e revistas passaram a retratar, com mais frequência, figuras humanas de forma jornalística e literária.

Conforme Sodré e Ferrari (1986), o perfil enfoca uma pessoa - seja uma celebridade, um tipo popular - mas sempre o focalizado é o protagonista da história de sua própria vida. Na visão dos autores, o personagem pode ser visto de três formas: como personagem indivíduo - quando o texto centra-se na descrição da atitude do sujeito perfilado; como personagem tipo - quando se trata de pessoa notória; e como personagem caricatura - quando o que está em foco é o grotesco. Essa classificação dá alguma base para se pensar as formas do gênero, mas, para a visão crítica aqui adotada, mostra-se insuficiente, já que a perspectiva dos autores é a de um discurso jornalístico transparente, que apenas relataria fatos entendidos como "reais". Nesse sentido, por exemplo, eles afirmam sobre o "personagem-caricatura": "É natural que, de vez em quando, encontremos sujeitos estranhos, de gestos grotescos e atitudes mirabolantes, com acentuada tendência à exibição" (SODRÉ; FERRARI, 1986, p. 136). Esse tipo de posicionamento, típico do discurso jornalístico hegemônico, não incorpora conceitos como representação e construção simbólica da realidade. Desse modo, faz parecer que termos como "estranho", "grotesco", "mirabolante" não sejam construções do discurso, mas expressões de um suposto real. Reproduz-se assim, também, a representação do jornalismo como isento e imparcial.

Na prática cotidiana, contudo, o perfil é muitas vezes mobilizado para enaltecer ou, ao contrário, para desconstruir a imagem positiva de determinado sujeito social, ou apenas para reproduzir os discursos dominantes, nesse caso pondo em cena os mesmo sujeitos já legitimados sob as mesmas lentes previsíveis, de acordo com os valores e práticas dominantes em determinado momento histórico.

Uma leitura crítica do perfil deve colocar em questão as partes do mundo que nele são retratadas, investigando essa ocorrência em função de determinadas ideologias, discursos e práticas. No caso dos perfis da campanha em questão, tem-se narrativas de superação de seis sujeitos, apresentadas de forma muito semelhante: iniciam-se com o relato de uma dificuldade do passado, algum desejo ou vontade do sujeito retratado; em seguida, é descrita a "luta enfrentada" por ele para superar o desafio e, finalmente, chega à "vitória”, apresentada como a conquista de uma suposta posição de destaque no setor profissional. Essas narrativas são perpassadas por expressões relacionadas a determinados passos representados como "decisivos", que remetem aos degraus de uma trajetória considerada bem-sucedida. Vejamos os exemplos abaixo:

\section{(4) "Foi o passo que mudou sua vida" (Céu de brigadeiro)}

\footnotetext{
${ }^{7}$ Esse rótulo pode ser visualizado no canto superior direito de todos os exemplares do gênero, que estão anexados em formato jpg no final deste trabalho.

${ }^{8}$ Ao afirmar que o perfil relata um personagem real, o autor demonstra possuir uma visão pautada no discurso jornalístico hegemônico, mas, em uma perspectiva sócio-histórica, se poderia dizer que todo personagem é criado; é efeito de um discurso.
} 
(5) "Esse passo mudou completamente o rumo de sua trajetória"

(No caminho dos astros)

(6) "[...] ele deu outro grande passo rumo a sua independência [...]"

(Game over? Sem chance!)

(7) “[... Luis deu o primeiro passo de sua jornada para o sucesso [...]"

(Um expert das baladas)

Pode-se dizer que a inclusão de determinados passos, caracterizados nas narrativas como decisivos, remete ao slogan da própria marca, que afirma, no modo imperativo: "Continue caminhando". Ao mesmo tempo em que descreve a natureza da dificuldade envolvida na conquista do sucesso, a existência dos passos homogeneíza os perfis e simplifica a trajetória dos sujeitos, criando um modelo de homem a ser imitado: um homem apresentado como liberal, guerreiro e sofisticado. As histórias, contudo, apagam qualquer traço das opressões sociais ou das possibilidades de transformação por meio da organização coletiva, ou seja, reforçam o mito disseminado na sociedade moderna capitalista de que a solução para os problemas depende apenas do esforço e comprometimento individuais.

Outro aspecto que fica evidente nos publieditoriais analisados é a adjetivação. No jornalismo, uma vez que diversos manuais de redação, como o de O Estado de São Paulo (MARTINS FILHO, 1997), orientam os profissionais a não usarem adjetivos ${ }^{9}$, é incomum que os textos dessa esfera tenham farta adjetivação. Já em textos publicitários, esse recurso é utilizado com mais frequência, o que reforça o caráter de hibridização do gênero. Esses adjetivos qualificam positivamente as ações dos sujeitos. Vejamos abaixo:

(8) No ano seguinte, ele fundou a Cavok, pioneira em operações para aviação executiva no país.

(9) [...] numa grande companhia aérea.

(10) [...] para tornar a Cavok mais competitiva no mercado internacional.

(11) Este ano, Mauro deu outro grande passo. (Céu de brigadeiro)

(12) Hoje, é uma referência em moda, entretenimento, cultura, comportamento e turismo. A revista é um $\underline{\text { sucesso }}$ não só por aqui [...]

(Expert em baladas)

(13) [...] se impôs metas ambiciosas, como trabalhar no hotel Ritz-Carlton, em Paris. (Conquista com sabor)

(14) [...] criar um software $\underline{\text { barato }}$ para monitorar o nível dos reservatórios [...] (A água nossa de cada dia)

Nos excertos destacados, por meio da adjetivação, o produtor do texto atribui a determinados objetos ou conceitos qualidades que são subjetivas, ou seja, não são objetivamente verificáveis. Por exemplo, uma grande companhia aérea comparada com quais? Qual o parâmetro para afirmar que uma revista é referência em cinco áreas tão diferentes? O que determina o sucesso da revista? Sua tiragem? Número de leitores, assinantes? Uma meta é ambiciosa para quem? Quem afirmou isso? O próprio entrevistado, ou o produtor do texto inferiu que, como se trata de trabalhar no restaurante de um hotel de luxo, a meta é ambiciosa, quando se trata de

${ }^{9}$ Essa recomendação faz com que o discurso jornalístico simule um efeito de imparcialidade. 
um cidadão brasileiro? O que significa ser um software $\underline{\text { barato }}$ ? Barato comparado ao quê? Alguns adjetivos estão relacionados ainda a atributos que são considerados desejáveis no âmbito do discurso empresarial, como competitiva e pioneira. O que se observa é que os discursos mobilizados nos textos são valorados positivamente e sempre acabam enaltecendo a ação individual dos sujeitos, colocando-os como modelos a serem seguidos. Esse aspecto será mais detalhadamente tratado no próximo tópico.

\subsection{A CONSTITUIÇÃO DA IDENTIDADE NA FRONTEIRA ENTRE JORNALISMO E PUBLICIDADE}

A identidade é uma construção discursiva e cultural que se evidencia como a marca caracterizadora de determinado sujeito. Consiste, segundo Castells (2006), em um "[...] processo de construção de significado com base em um atributo cultural, ou ainda um conjunto de atributos culturais inter-relacionados, o(s) qual(ais) prevalece(m) sobre outras fontes de significado." (2006, p. 22). Esse autor aponta três formas pelas quais a identidade se mostra em relação aos discursos aos quais se relaciona: a legitimadora, que reproduz o discurso de base (por exemplo, o nacionalismo do estado-nação); a de resistência, que aparece como uma deriva e um questionamento do discurso que lhe dá base (o islamismo que questiona o estado-nação e se coloca como uma identidade supraterritorial); e a identidade de projeto, que aparece no bojo de discursos recriadores da realidade e das relações sociais (o feminismo lesbiano, por exemplo).

Assim como os feminismos são tipos de identidade, também as masculinidades o são. Elas se modificam conforme a época, mas é possível perceber uma masculinidade de longa duração, a que Connell (2003 [1995]) chamará de masculinidade hegemônica, ligada ao poder patriarcal.

Nos textos analisados nesta pesquisa, as masculinidades - ainda que em sintonia com um período recente/contemporâneo (a modernidade tardia) - estão bastante relacionadas a essa masculina hegemônica. Também, justamente por esse motivo e por reproduzir o discurso dominante na atualidade (o neoliberalismo), a masculinidade da campanha de Johnnie Walker tende a ser uma identidade legitimadora.

Voltando à campanha, a empresa, conforme já mencionado acima, veiculou um anúncio pedindo que os leitores enviassem um texto relatando um episódio de sua vida que tivesse sido marcante. Depois disso, segundo o anúncio, algumas histórias seriam selecionadas por repórteres, que posteriormente iriam entrevistar os escolhidos. O objetivo, nesses textos, parece ser transformar o sujeito representado em um personagem, promovendo a expectativa de um mundo que vai além do cotidiano imediato. Isso fica evidenciado na figura 5 , extraída desse anúncio.

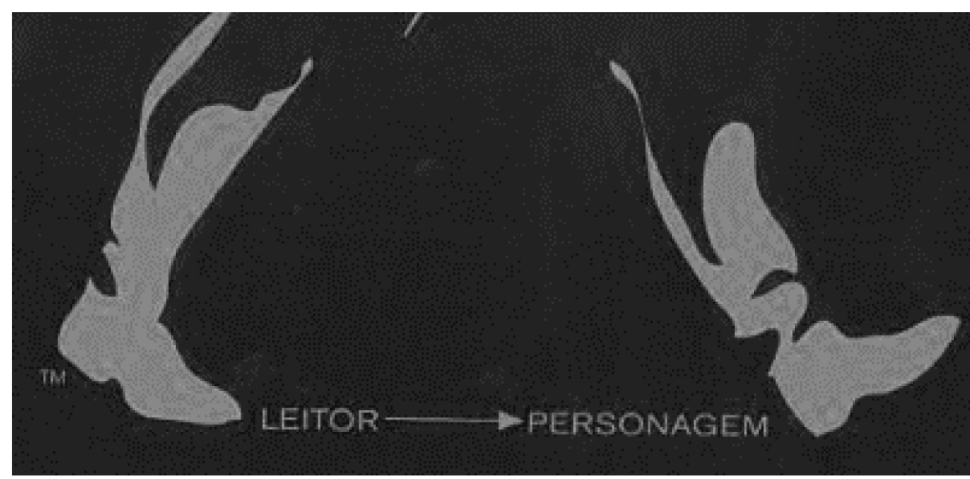

Figura 5: Recorte do primeiro anúncio da marca Johnnie Walker ${ }^{10}$.

Fonte: Recorte do anúncio

O resultado são perfis jornalísticos que trazem uma narrativa de superação de desafios, a partir do que denominam ser um "passo decisivo". O que se observa como característica geral dos exemplares é o fato de terem sido selecionados homens, supostamente bem-sucedidos para associarem uma imagem entendida como positiva à marca, reforçando a representação do consumidor usual

${ }^{10} \mathrm{O}$ anúncio completo pode ser visualizado nos anexos deste trabalho. 
da bebida e da classe social a qual ele pertence. Essa postura acaba por converter a pessoa em uma marca. Ao expor uma trajetória individual fortemente associada com valores considerados positivos na sociedade contemporânea, o sujeito acaba se colocando no mesmo plano da marca e tornando-se, ele mesmo, um objeto de culto e, portanto, de consumo. Além disso, os sujeitos são sempre do sexo masculino, e, portanto, caracterizados como agentes (em oposição à mulher, que, nas propagandas de cervejas, geralmente é mostrada como objeto de contemplação e consumo). A forma como a mulher é retratada em comerciais de cerveja foi investigada por Ouverney (2008). A pesquisa sobre os componentes não verbais em comerciais televisivos mostrou que não se vende somente a cerveja, mas também uma imagem estereotipada da mulher: "[...] fútil, que é constantemente denotada como sexy, provocativa, atraente ao extremo, uma mulher cujo objetivo centra-se em seduzir o homem” (OUVERNEY, 2008, p. 61).

No caso do corpus enfocado nesta pesquisa, a seleção dos personagens do sexo masculino, além de criar uma identificação com o público leitor das publicações, coloca em destaque determinados perfis identitários e os apresenta como verdadeiros símbolos de sucesso na sociedade do novo capitalismo. Esses personagens fazem pressupor outros, que lhes são opostos e que não aparecem.

Um caso emblemático é o do texto intitulado "Game Over? Sem chance!", que traz a história de Rafael, que começou a trabalhar aos 14 anos porque não queria depender dos pais. Por trás do relato de um jovem que escolheu ingressar no mercado de trabalho, há inúmeras histórias silenciadas de jovens que começam a trabalhar não por opção, mas porque precisavam contribuir financeiramente para ajudar no sustento da família. Outro sujeito que teve oportunidade de escolha é Peter Katzenbeisser, que tinha 16 anos quando decidiu não seguir a carreira do pai, que trabalhava em uma grande montadora de veículos. Peter é um jovem chef de cozinha, apresentado no texto intitulado "Uma conquista com sabor". O perfil identitário é de um profissional que trabalha com gastronomia, o que pode ser considerado um item de distinção de classe; o pobre come sanduíche ou leva marmita de casa para o horário de almoço, já quem é apresentado como bem-sucedido se vê no direito de ser conhecedor de vinhos, de cervejas artesanais e de especialidades culinárias.

Esse discurso neoliberal do sucesso e da superação está fortemente vinculado ao discurso empresarial do empreendedorismo, como se pode ver no texto intitulado "Céu de brigadeiro", que explora a história de um cidadão que abriu a própria empresa em um nicho de mercado inexistente no Brasil.

(15) "Como a empresa não se interessou, decidi seguir por conta própria"

(16) "Resolvi que era hora do meu vôo solo"

Outro exemplo da recorrência desse discurso pode ser visto no exemplar "Um expert das baladas":

(17) “[...] largou as boas comissões e criou a revista Lounge".

O texto "Game over? Sem chance!" também destaca as ações de um sujeito na trajetória rumo ao que é considerado sucesso empresarial:

(18) “[...] ele deu outro grande passo rumo a sua independência: criou uma marca própria [...]"

Finalmente, ainda se observa o destaque positivo à ação empreendedora no texto "Uma conquista com sabor". Depois de trabalhar em restaurantes na Europa, o sujeito retornou ao Brasil para abrir seu próprio negócio:

(19) "Hoje é dono do Ello Gastronômico [...]"

Outro discurso evidenciado nos exemplares do gênero é o ecológico, a exemplo do texto "A água nossa de cada dia”, no qual o desafio parece ser "salvar o planeta" e, ao mesmo tempo, ser bem-sucedido profissionalmente. Isso pode ser percebido no seguinte trecho: “A idéia deles era ajudar o planeta e criar algo rentável [...]”. A partir dessa associação entre 'ajudar' (discurso ecológico) e 'algo rentável' (discurso empresarial), percebe-se que o herói atual não precisa mais ser alguém abnegado; são os traços do heroísmo 
sendo conduzidos para o discurso do mercado. De acordo com essa visão de mundo não é preciso nem sair da cadeira para ajudar o planeta. É o que indica uma das frases finais do texto: "Hoje, Diogo promove a sustentabilidade em frente ao computador".

Um termo que contribui para compreender o papel dos sujeitos retratados no gênero é o conceito de ator social. Van Leeuwen (1996) usa a expressão para se referir à representação social dos sujeitos na linguagem: "Representações incluem ou excluem atores sociais para atender seus interesses e propósitos em relação aos leitores para quem eles se destinam” (1996, p. 38 - tradução da autora). Para ele, as práticas sociais envolvem conjuntos específicos de atores sociais que desempenham papéis nessas representaçoes, por exemplo, "[...] quem é representado como agente (ator), quem é como paciente (objetivo) com respeito a uma dada ação?" (VAN LEEUWEN, 1996, p. 42-43 - tradução da autora). Com base nessa teoria, observa-se que os atores sociais representados no gênero aqui selecionado desempenham o papel de agentes. Isso pode ser constatado pelo uso constante de verbos na voz ativa e que demonstram a vontade/desejo do sujeito. $\mathrm{O}$ uso de verbos na primeira pessoa do presente do indicativo também demonstra o foco no agente:

(20) "Quero ser referência em redução de consumo de água".

(A água nossa de cada dia)

(21) “[...] quero ter meu próprio bistrô".

(Uma conquista com sabor)

(22) "Hoje fabrico mais de 50 acessórios para games".

(Game over? Sem chance!)

Trata-se de um discurso que coloca esses sujeitos como exemplos para outros. Daí suas identidades serem representadas com agência, destacada pelo uso de determinados verbos.

Além disso, observa-se a utilização constante de outros verbos de ação que reforçam o aspecto empreendedor, supostamente positivo, dos atores sociais, e que estão diretamente ligados à esfera empresarial, como, por exemplo:

(23) "[...] negociou o controle acionário da Cavok [...]"

(Céu de brigadeiro)

(24) Hoje, Diogo promove a sustentabilidade [...]"

(A água nossa de cada dia)

(25) "Passei a desenvolver as ideias aqui [...]"

(Game over? Sem chance!)

(26) "Agora, ele planeja seu próximo passo [...]"

(Uma conquista com sabor)

O discurso empresarial do empreendedorismo ainda é explicitamente marcado no trecho final de quatro dos seis publieditoriais. Nesses excertos, é destacado o desejo dos atores sociais de continuarem sua suposta trajetória de sucesso no futuro, reforçando, novamente, a ação do indivíduo em detrimento de uma possível ação na sociedade, e seu posicionamento como modelo a ser seguido:

(27) "Agora, ele planeja seu próximo passo: Em cinco anos, quero ter meu próprio bistrô"

(Uma conquista com sabor) 
(28) "Luis, claro, quer ir mais longe e pretende lançar revistas de gastronomia, negócios e decoração" (Um expert das baladas)

(29) "Seus próximos passos: fazer pós-graduação em Harvard e cursos de aperfeiçoamento na Nasa" (No caminho dos astros)

(30) “[... ele está prestes a realizar um sonho antigo: pilotar seu próprio avião”

(Céu de brigadeiro)

Observa-se pelos vários exemplos destacados que uma metáfora ocupa o plano central. Trata-se do "passo" que, tanto representa a anunciada "superação" dos sujeitos convocados, denominados personagens, quanto representa o produto anunciado, na medida em que se trata da logomarca desse produto.

O tratamento como personagem coloca os sujeitos em um plano idealizado que os glamuriza e, ao mesmo tempo, os descompromete das implicações de ceder o nome e a própria história a uma transação comercial. Elabora-se também um discurso romântico a partir de adjetivações como: “[...] grandes histórias sobre trajetórias, coragem e inspiração [...]”. Considera-se o discurso como romântico, pois ele cria uma aura "dourada" para histórias que não apresentam, efetivamente, grandes superações ou situações de extrema privação, exploração ou opressão. São perfis de profissionais liberais que apresentam certa representação de sucesso e que se enquadram nos parâmetros do discurso neoliberal: individualismo, valorização do mercado empresarial, das ações empreendedoras, da ciência ocidental positivista e, nesse caso, essencialmente voltada ao fazer tecnológico e à visão ecológica (com certa tonalidade alarmista).

\section{CONCLUSÃO}

A partir da análise realizada foi possível responder à questão de pesquisa lançada no início do trabalho: Como o publieditorial da campanha "Aonde um passo pode te levar" da Johnnie Walker se constitui como gênero e prática social, e como constitui identidades (particularmente a masculinidade) no contexto da modernidade tardia? Para dirimir esse questionamento, apontou-se dois objetivos. O primeiro objetivo foi explorar a hibridização jornalístico-publicitária do gênero publieditorial. Nesse aspecto, constatou-se que a campanha se compõe basicamente de dois conjuntos de elementos verbais: os jornalísticos e os publicitários, que se apresentam intercalados na formatação do gênero. No conjunto jornalístico, que foi o foco dessa pesquisa, verificou-se regularidades nas narrativas da história de vida dos sujeitos, que se evidenciam como forma de relacionar a marca a uma trajetória considerada bem-sucedida, atrelando-a a um indivíduo que se pretende que sirva de modelo para os demais. Outro aspecto pontuado foi a legislação que regulamenta a propaganda de bebidas alcoólicas. Percebeu-se que, ao ser proibida de utilizar meios que induzam diretamente ao consumo, a empresa aqui enfocada optou por criar peças publicitárias que disfarcem a situação, explorando temas relacionados ao sucesso pessoal.

O segundo objetivo foi detalhar os modos de constituição da identidade masculina na fronteira entre jornalismo e publicidade no contexto da modernidade tardia. A identidade dos sujeitos representados é construída, sobretudo, por meio de perfis jornalísticos que descrevem sua trajetória profissional, que é pontuada por supostas dificuldades, apresentadas como determinados "passos". A estruturação da narrativa em passos demonstra a necessidade de reafirmar a identificação com a marca e o slogan da empresa. Finalmente, a pessoa atinge seu objetivo e alcança uma posição considerada de destaque. Mas, ainda assim, a trajetória não termina: o sujeito salienta seu desejo de atingir novas conquistas, reforçando o estereótipo do homem heroico que sempre pode alcançar uma façanha maior. Dessa forma, mostra-se, por meio de exemplos, que a trajetória dos profissionais trazida nos perfis apresenta uma representação de sucesso que se enquadra nos parâmetros do discurso neoliberal: individualismo, valorização do mercado empresarial, das ações empreendedoras, da ciência ocidental positivista e essencialmente voltada ao fazer tecnológico e visão ecológica alarmista. 
Considera-se, nesse sentido, que esta pesquisa contribuiu para compreender a natureza dos textos que reúnem informação e publicidade, já que, como afirma Fairclough (1992 [2001])), eles são cada vez mais comuns em diversas ordens de discursos institucionais da sociedade contemporânea. Por conta do movimento de hibridismo cultural, social e discursivo que vem se aprofundando nas últimas décadas, certas fronteiras de discurso estão sendo diluídas, o que causa uma profusão de gêneros com contornos pouco nítidos. O publieditorial, assim como outros textos veiculados na mídia, é resultado dessa indefinição de fronteiras. A ascensão desse gênero nas mídias impressas se dá, sobretudo, pela necessidade, percebida pelo marketing das empresas, de valorizar seu produto, apresentando-o por meio de textos jornalísticos, que detêm, muito provavelmente em função do discurso jornalístico da objetividade e da imparcialidade, maior credibilidade e legitimidade perante os leitores que a propaganda explícita, veiculada na forma de anúncios pagos. Por esse motivo, a atuação publicitária da atualidade, cada vez mais competitiva e compulsiva, estimula seus profissionais a criarem gêneros híbridos, incorporando aos gêneros institucionalizados elementos promocionais.

Considera-se que a pesquisa aqui empreendida demonstra que o estudo dos gêneros jornalísticos e publicitários em uma perspectiva crítica pode oportunizar a ampliação dos conhecimentos sobre essas práticas que se dão de forma cada vez mais hibridizada, e ainda favorece o debate e a formação do cidadão para uma visão crítica das mídias e de seus produtos culturais.

\section{REFERÊNCIAS}

ABRAMO, P. Padrões de manipulação na grande imprensa. São Paulo: Editora Fundação Perseu Abramo, 2003.

BHATIA, V. K. Worlds of written discourse: a genre-based view. London; New York: Continuum, 2004.

BONINI, A. Critical genre analysis and professional practice: the case of public contests to select professors for Brazilian public universities. Linguagem em (dis)curso, Tubarão, v. 10, n. 3, p. 485-510, 2010.

BONINI, A . Mídia, suporte e hipergênero: os gêneros textuais e suas relações. Rev. bras. linguist. apl. [online], vol.11, n.3, p. 679-

704, 2011. Disponível em: http://www.scielo.br/scielo.php?pid=S1984-63982011000300005\&script=sci abstract\&tlng=pt. Acesso em: 02 nov. 2012.

BONINI, A. Análise Crítica de Gêneros Jornalísticos. In: ENCONTRO NACIONAL DE PESQUISADORES EM JORNALISMO, 10, 2012, Curitiba. Anais... Pontifícia Universidade Católica do Paraná , 2012.

BRASIL. Lei no 9.294, de 15 de julho de 1996. Dispõe sobre as restrições ao uso e à propaganda de produtos fumígeros, bebidas alcoólicas, medicamentos, terapias e defensivos agrícolas, nos termos do $\$ 4^{\circ}$ do art. 220 da Constituição Federal. Disponível em: http://www.planalto.gov.br/ccivil 03/leis/19294.htm. Acesso em: 10 mar. 2014.

CARDOSO, J. R. A imagem como recurso persuasivo da propaganda. In: ALMEIDA, D. B. L. de (org.). Perspectivas em análise visual: do fotojornalismo ao blog. João Pessoa: Editora da UFPB, 2008. p. 54-70.

CASTELLS, M. O poder da identidade. São Paulo: Editora Paz e Terra, 2006. v. 2.

CONNELL, R. Masculinidades. México: Universidad Nacional Autónoma de México, 2003 [1995].

CHEONG, Y. Y. The construal of ideational meaning in print advertisements. In: O'HA LLORAN, K. L. (ed.). Multimodal discourse analysis: systemic functional perspectives. London/New York: Continuum, 2004. p. 164-195.

CHOULIARAKI, L.; FAIRCLOUGH, N. Discourse in late modernity: rethinking critical discourse analysis. Edinburgh University Press: 1999. 
CONSELHO NACIONAL DE AUTORREGULAMENTAÇÃO PUBLICITÁRIA. Código Brasileiro de Autorregulamentação Publicitária. (1980). Disponível em: <http://www.conar.org.br/codigo/codigo.php $>$. Acesso em: 22 mar. 2014.

FAIRCLOUGH, N. Language and Power. 2. ed. Pearson Education Limited: 1989 [2001].

FAIRCLOUGH, N. Discurso e mudança social. Izabel Magalhães, coordenadora da tradução, revisão técnica e prefácio. Brasília: Editora Universidade de Brasília, 1992 [2001].

FAIRCLOUGH, N. Critical discourse analysis: papers in the critical study of language. London: Routlegde, 1995.

FAIRCLOUGH, N. Technologisation of discourse. In: COULTHARD, C.; COULTHARD, M. (ed.). Texts and practices: readings in critical discourse analysis.. London \& New York: Routledge, 1996. p. 71-78.

FAIRCLOUGH, N. Analysing discourse: Textual analysis for social research. London: Routlegde, 2003.

GIDDENS, A. As consequências da modernidade. Trad. Raul Fiker. São Paulo: Unesp, 1991.

GOMES, M. C. A. A questão do hibridismo na relação entre gêneros discursivos e mudança social. Revista de Estudos da Linguagem. v. 13, n.1, jan/jun.2005. p.155-170. Disponível em: http://www.relin.letras.ufmg.br/revista/upload/07-Maria-Carmen-Aires.pdf. Acesso em: 11 dez. 2013.

GOMES, M. C. A. Discutindo as identidades sociais no gênero discursivo híbrido reportagem-publicidade. In: EMEDIATO, Wander; MACHADO, Ida; MENEZES, Wiliam. (org.). Análise do discurso: gêneros, comunicação e sociedade. 1.ed. Belo Horizonte: NAD, UFMG, POSLIN, 2006, v. 1, p. 200-213. Disponível em: http://www.letras.ufmg.br/site/ELivros/An\%C3\%A1lise\%20do\%20Discurso\%20-\%20G\%C3\%AAneros,\%20Comunica\%C3\%A7\%C3\%A3o\%20e\%20Sociedade.pdf

GOMES, M. C. A. Gêneros da Mídia: configurando o gênero reportagem-publicidade. In: SIMPÓSIO INTERNACIONAL DE GÊNEROS TEXTUAIS - SIGET, 4, 2007, Tubarão. Anais... Tubarão: Unisul, 2007. v. 1. p. 1344-1356. Disponível em: http://linguagem.unisul.br/paginas/ensino/pos/linguagem/cd/Port/80.pdf. Acesso em: 02 dez. 2012.

LAGE, N. Teoria e técnica do texto jornalístico. Rio de Janeiro, Elsevier, 2005.

LIMA, S. C. de. Hipergênero: agrupamento ordenado de gêneros na constituição de um macroenunciado. Tese (Doutorado em Linguística) - Programa de Pós-Graduação em Linguística, Instituto de Letras. Departamento de Linguística, Português e Línguas Clássicas, Universidade de Brasília, Brasília, , 2013.

MARSHALL, L. O jornalismo na era da publicidade. São Paulo: Summus, 2003.

MARTINS FILHO, E. L. Manual de redação e estilo de O Estado de S. Paulo. São Paulo: O Estado de S. Paulo, 1997.

MEURER, J. L. Gêneros textuais na análise crítica de Fairclough. In: MEURER, J. L.; BONINI, A.; MOTA-ROTH, D. (org.). Gêneros: teorias, métodos, debates. São Paulo: Parábola Editorial, 2005. p. 81-106.

MOREIRA JÚNIOR, S. Regulação da publicidade de bebidas alcoólicas. Consultoria Legislativa do Senado Federal. Coordenação de estudos. Textos para discussão. Brasília, 2005. Disponível em: http://www12.senado.gov.br/publicacoes/estudos-legislativos/tiposde-estudos/textos-para-discussao/td-20-regulacao-da-publicidade-das-bebidas-alcoolicas. Acesso em: 01 abr. 2014.

MOTTA-ROTH, D. Questões de metodologia em análise de gêneros. In: SIMPÓSIO NACIONAL DE ESTUDO DOS GÊNEROS TEXTUAIS, 2, , União da Vitória, PR: FAFI. 06 de agosto de 2004. 
MOTTA-ROTH, D. Análise crítica de gêneros: contribuições para o ensino e a pesquisa de linguagem. DELTA, v. 24, n. 2, p. 341$383,2008$.

MOTTA-ROTH, D.; MARCUZZO, P. Ciência na mídia: análise crítica de gênero de notícias de popularização científica. Revista Brasileira de Linguística Aplicada (RBLA), Belo Horizonte, v. 10, n. 3, p. 511-538, 2010.

OUVERNEY, J. R. A mulher retratada em comerciais de cerveja: venda de mulheres ou de bebidas? In: ALMEIDA, D. B. L. de (org.). Perspectivas em análise visual: do fotojornalismo ao blog. João Pessoa: Editora da UFPB, 2008. p. 37-53.

RAMALHO, V. Análise crítica da publicidade: um estudo sobre anúncios de medicamento. Cadernos de linguagem e sociedade, Brasília, v. 10, n. 2, p. 152-182, 2009.

SODRÉ, M.; FERRARI, M. H. Técnicas de reportagem: notas sobre a narrativa jornalística. São Paulo: Summus, 1986.

SWALES, J. Genre Analysis: English in academic and research settings. United Kingdom: Cambridge University Press, 1990.

Van DIJK, T. A. Discurso e poder. São Paulo: Contexto, 2010.

Van LEEUWEN, T. The representation of social actors. In: COULTHARD, C.; COULTHARD, M. (ed.). Texts and practices: readings in critical discourse analysis. London \& New York: Routledge, 1996. p. 32-70.

VILAS BOAS, S. Perfis: e como escrevê-los. São Paulo: Summus, 2003.

\section{(๑) $\circledast \Theta$}

Recebido em 14/12/2019. Aceito em 13/01/2020. 
ANEXO A - CAMPANHAS EM REVISTA

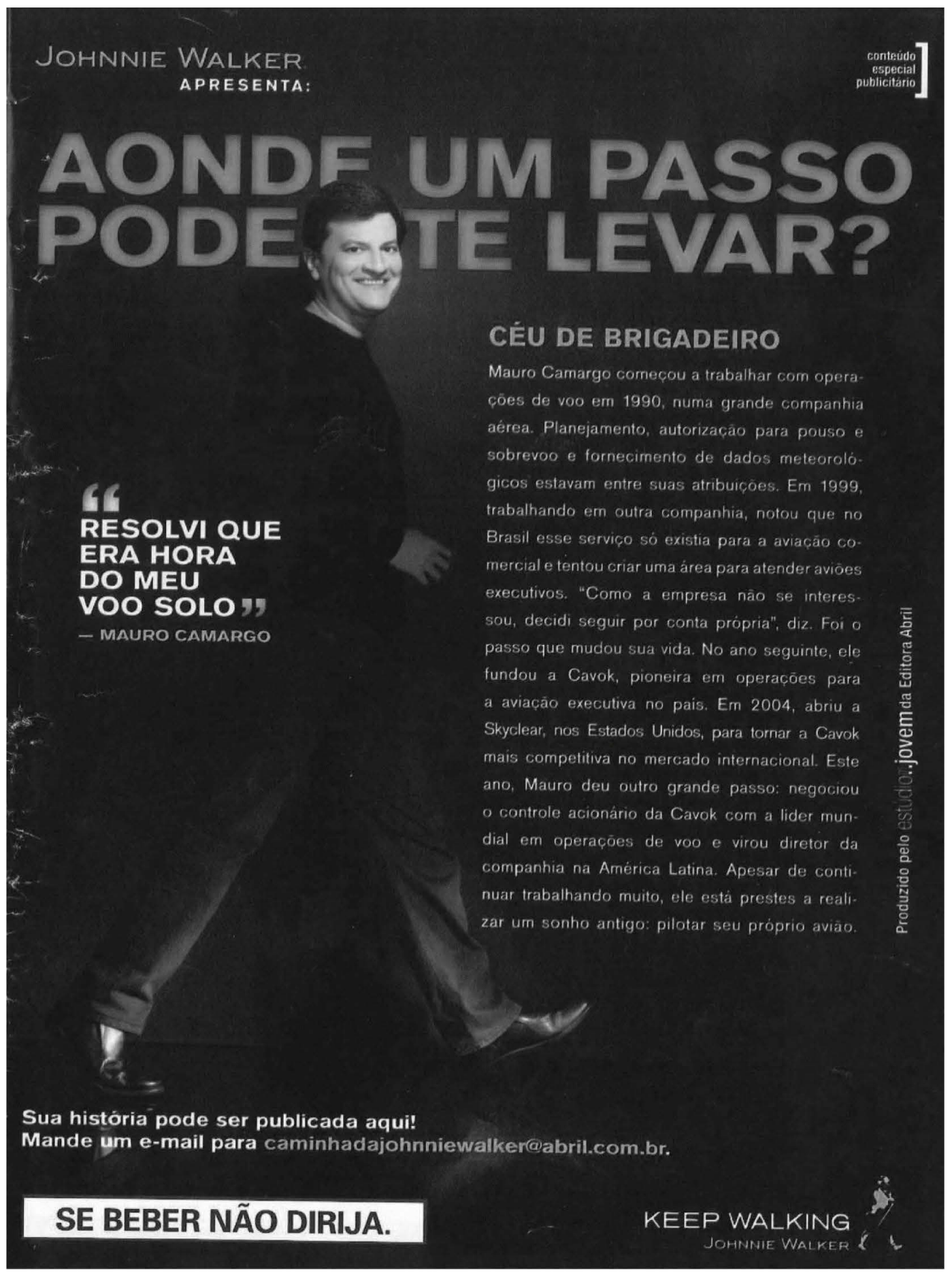




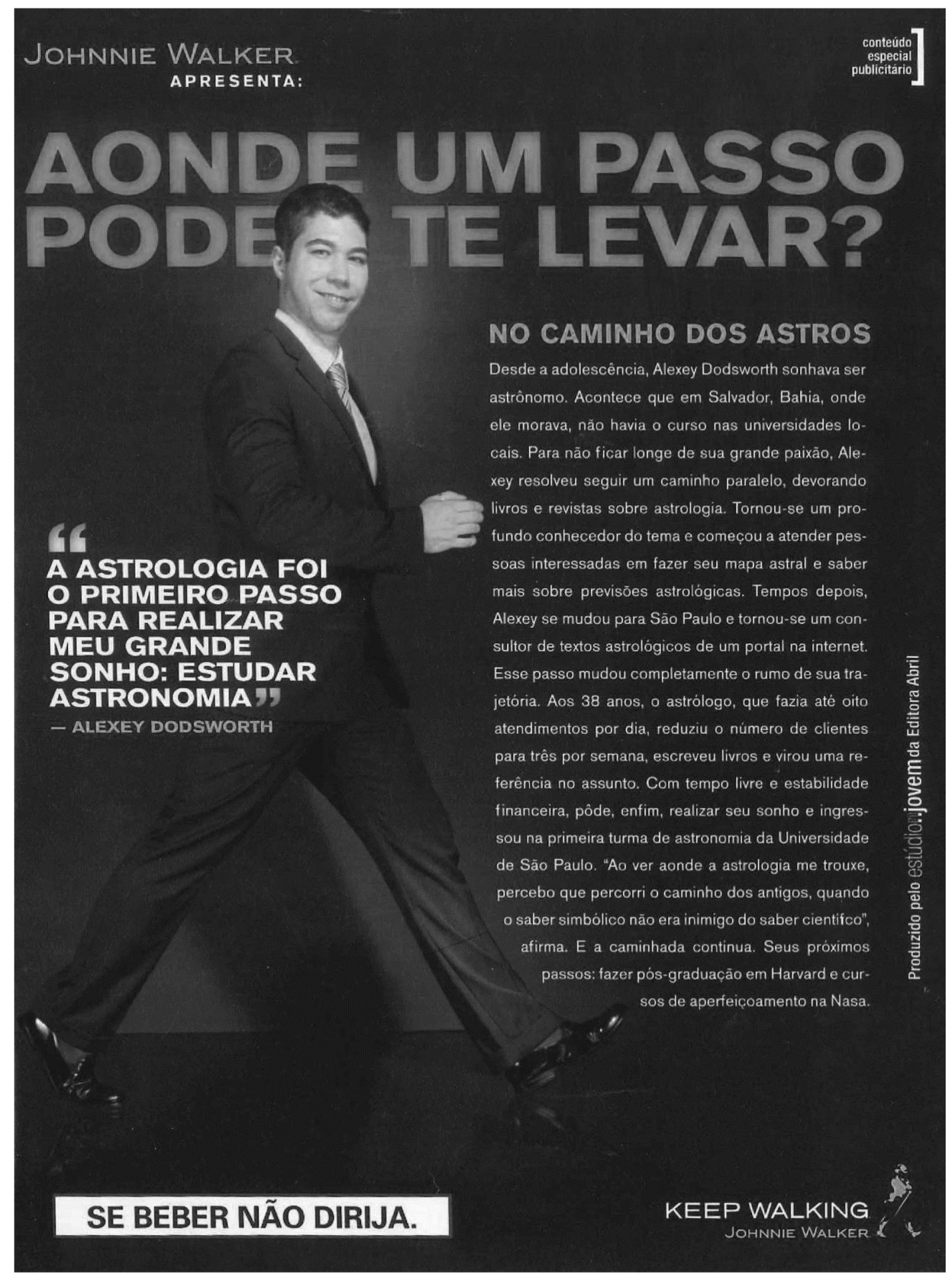




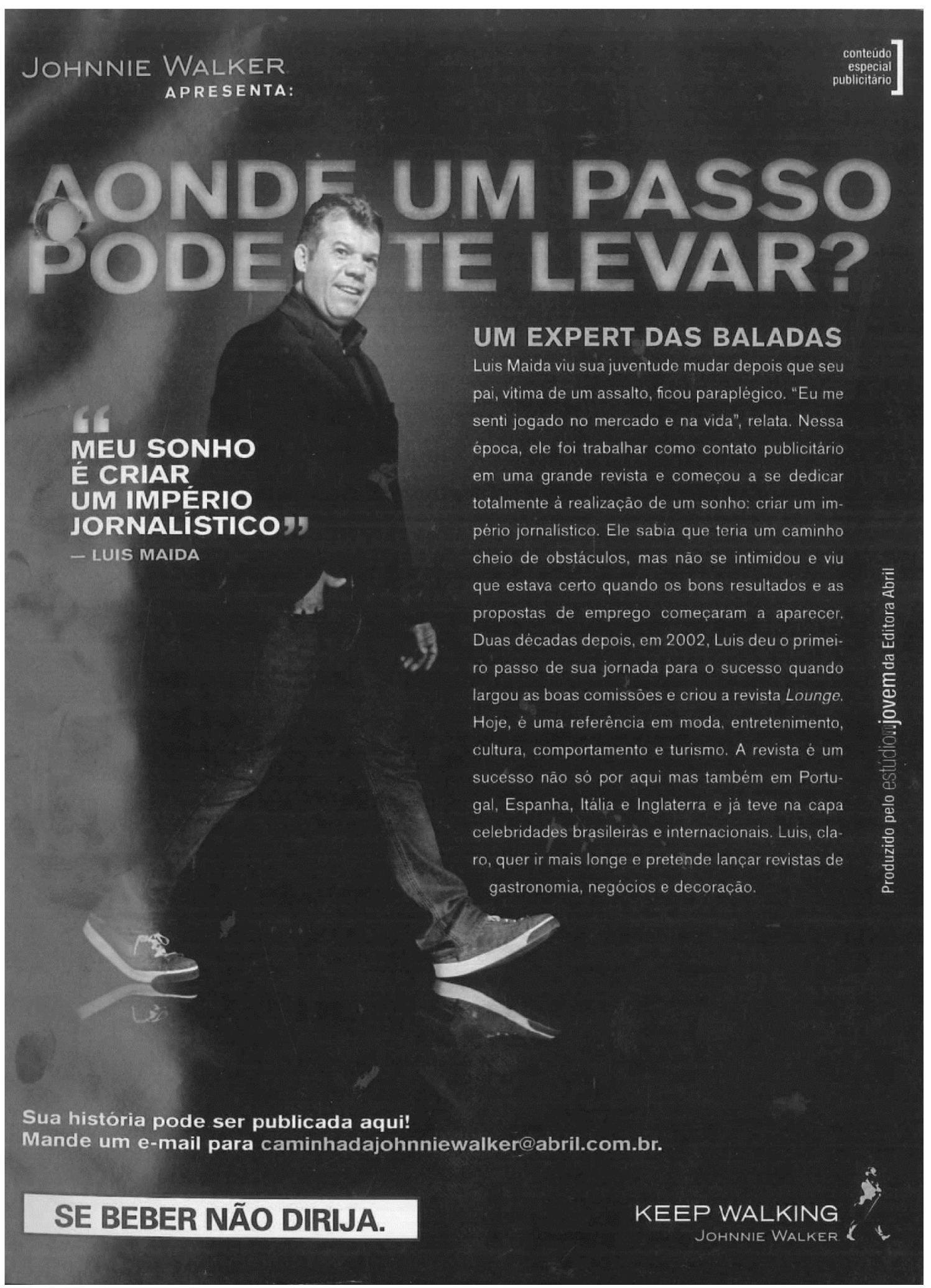




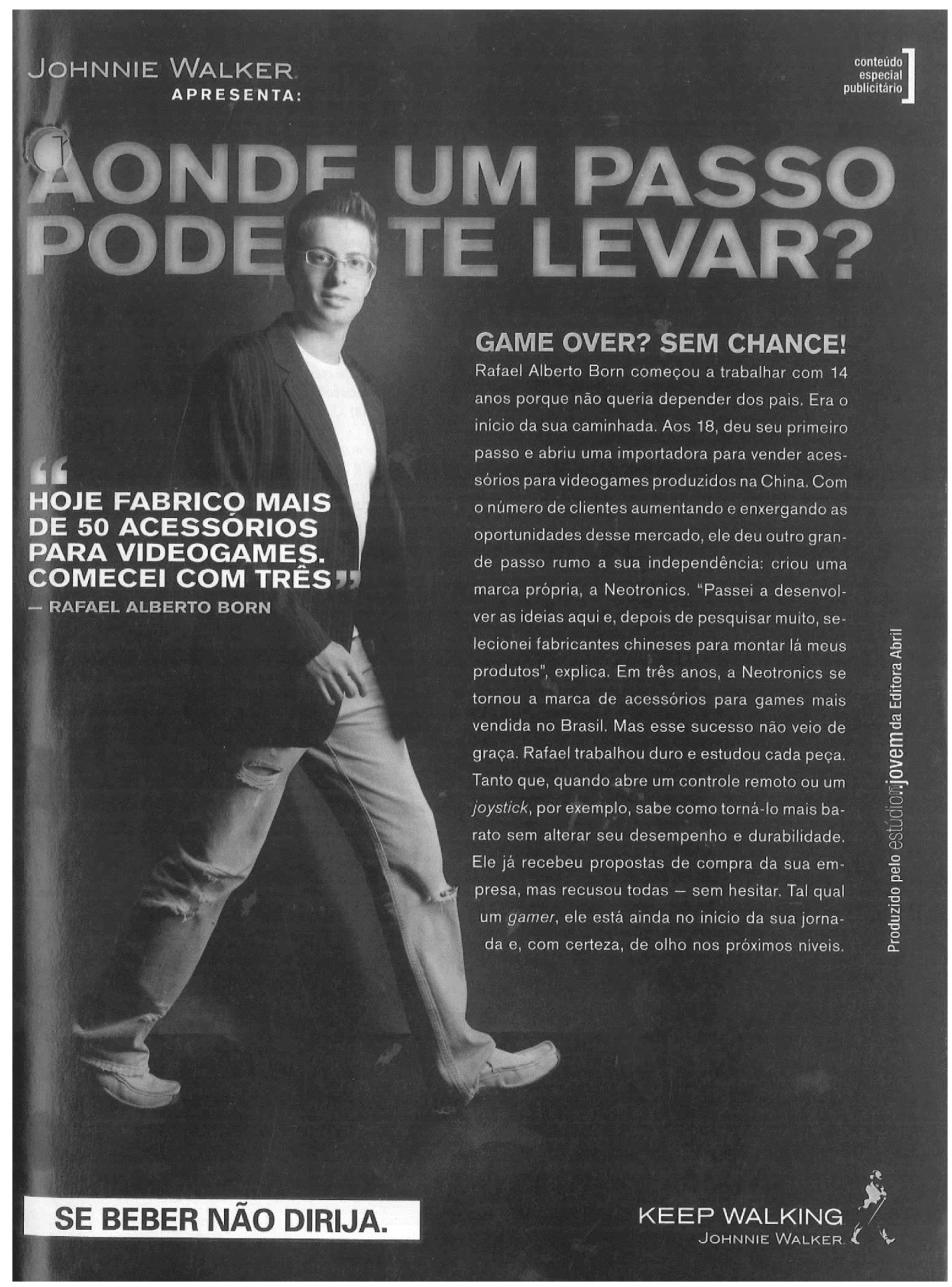




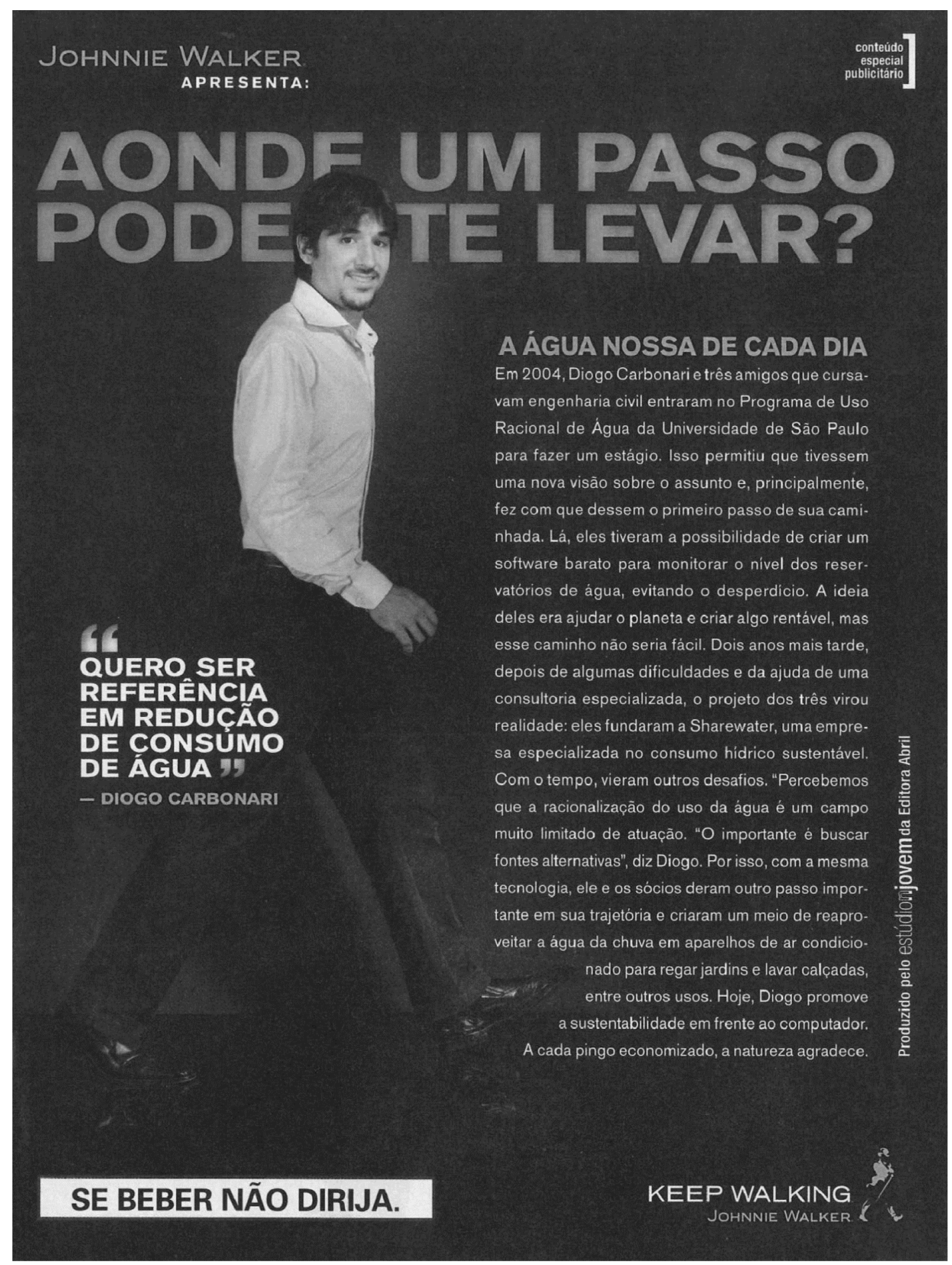




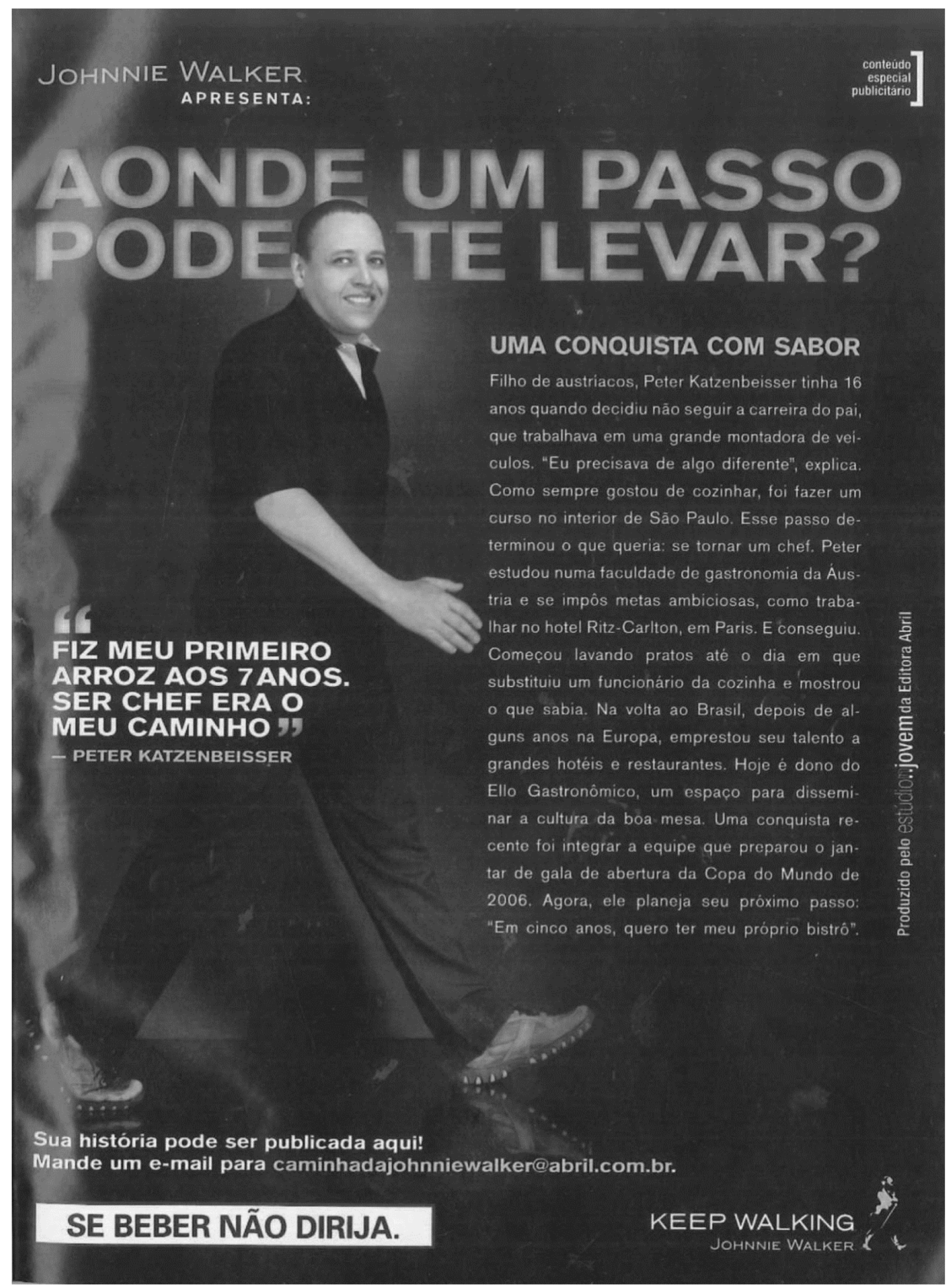

